\title{
PERBANDINGAN TAFSIR KATA FAQIR DAN MISKIN DALAM AL-QUR'AN
}

\author{
Muhammad Nurzansyah \\ amzsya@gmail.com \\ (Fakultas Agama Islam, Universitas Muhammadiyah Tangerang)
}

\begin{abstract}
Abstrak
Makalah ini membahas tentang pengertian fakir dan miskin dari tiga pandangan, menurut bahasa dan istilah, pengertian keduanya menurut para penafsir Al-Qur'an dan pengertian keduanya menurut ulama fiqh. Penulis menggunakan studi kepustakaan dengan metode tematik perbandingan di mana penulis menggunakan beberapa kamus bahasa Arab untuk menggali pengertian secara bahasa dan istilah. Untuk mengetahui pendapat para penafsir Al-Qur'an, maka penulis menggunakan 5 tafsir dengan 2 metode yang berbeda yaitu metode tafsir bi al-ma'thur dan metode tafsir bi al-ra'yi.yaitu : Tafsir Al-Qur'an al-'Adzim karya Ibnu kathir, Al-Siraj Al-Munir karya al-Syarbaini, , al-Nasafy karya al-Nasafy dan al-Dur alManthur fi al-Tafsir al-Ma'thur Karya al-Suyuthi, dan Al-Kasysyaf 'An Haqaiq al-Tanzil Wa 'Uyun al-Aqawil Fi Wujuh al-Ta'wil karya al-Zamakhsyary. Penulis juga menggunakan buku fiqh untuk mendapatkan pengertian keduanya dari para ulama fiqh. Dapat disimpulkan di sini bahwa (1) Pengertian fakir menurut bahasa adalah orang yang bangkrut yang membutuhkan sesuatu yang mencukupi kebutuhannya. Sedangkan kata miskin adalah orang yang diam tidak mampu bergerak atau berusaha dikarenakan kondisi kemiskinan yang menimpanya. (2) Para mufassir berbeda-beda di dalam menafsirkan kata fakir dan miskin. Ada yang mengatakan bahwa orang fakir lebih lemah kondisinya daripada orang miskin. Sebagian lagi berpendapat bahwa orang miskin lebih lemah kondisinya daripada orang Fakir. Ada mufassir myang menyamakan istilah Fakir dan miskin. Di samping itu ada pula yang membedakannya dengan menggunakan keterangan dari hadith nabi SAW dari Abu Hurairah R.A. (3) Dalam term fiqih, orang fakir adalah orang yang membutuhkan berbagai hal yang ia tidak sanggup untuk memeenuhinya. Sementara orang miskin adalah orang yang memiliki pekerjaan akan tetapi tidak dapat mencukupi berbagai kebutuhan hidupnya.
\end{abstract}

\section{Kata kunci : Fakir, Miskin, Fuqara, Masakin.}

\begin{abstract}
This paper studies about the definition of "Fakir and miskin" from three points of views. From etymology and terminology. From Quranic interpreters' opinion and from Islamic Juriprudence scholars.This study uses the library research with comparative theme method focusing on some Arabic dictionaries, five tafsir books with tafsir bi al-ma;thur and tafsir alra'yi methods And some Islamic jurisprudence scholar opinions in fiqh books. The conclusion of this study explains that (1) fakir means someone who is broke, while miskin is someone who can't live independently and work because of his/her famine.(2) some of mufassir said that fakir is poorer than miskin while others said that miskin is vice versa. Some mufassir have different points of views on fakir and miskin term. Some of them argued that fakir and miskin have something in common. Others argued that fakir and miskin are not the same. (3) Some of Islamic jurisprudence scholars said that fakir is someone who needs a lot of things
\end{abstract}


that he/she can't afford. While miskin is someone who has job but doesn't cover his/her daily and basic needs.

Key words : Fakir, Miskin, Fuqara, Masakin.

\section{A. Pendahuluan}

Sudah menjadi pemahaman umum bahwasanya kata faqir menunjukkan kepada manusia yang berada di dalam kondisi ekonomi yang paling bawah. Di dalam istilah bahasa Indonesia kata faqir diartikan dengan orang yang sangat berkekurangan; orang yang terlalu miskin: 2 orang yang dengan sengaja membuat dirinya menderita kekurangan untuk mencapai kesempurnaan batin; 3 aku (bagi pengarang dalam syair dan sebagainya). KBBI memberi contoh kaum faqir dan kaum miskin;2 orang-orang yang sangat kekurangan; ${ }^{1}$ Di dalam kesempatan lain KBBI mengartikan miskin dengan tidak berharta; serba kekurangan (berpenghasilan sangat rendah): Miskinpapa sangat miskin;.. ${ }^{2}$ Di dalam Al-Qur'an penyebutan kata faqir sering digandengkan dengan kata miskin. Sebagaimana disebutkan di dalam AlQur'an surat Al-Taubah ayat 60:

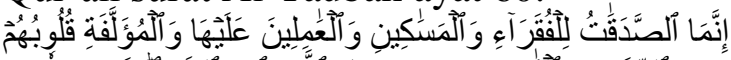

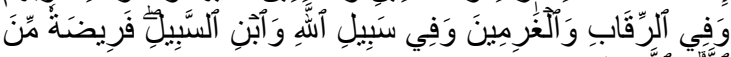

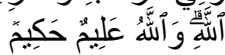

Sesungguhnya zakat-zakat itu, hanyalah untuk orang-orang fakir, orang-orang miskin, pengurus-pengurus zakat, para mu'allaf yang dibujuk hatinya, untuk (memerdekakan) budak, orang-orang yang berhutang, untuk jalan Allah dan untuk mereka yuang sedang dalam perjalanan, sebagai suatu ketetapan yang diwajibkan Allah, dan Allah Maha Mengetahui lagi Maha Bijaksana.

Berdasarkan ayat di atas yang berhak menerima zakat Ialah: 1. orang faqir: orang yang Amat sengsara hidupnya,

\footnotetext{
${ }^{1}$ https://www.kbbi.web.id/faqir

${ }^{2}$ https://www.kbbi.web.id/miskin
}

tidak mempunyai harta dan tenaga untuk memenuhi penghidupannya. 2. Orang miskin: orang yang tidak cukup penghidupannya dan dalam Keadaan kekurangan. 3. Pengurus zakat: orang yang diberi tugas untuk mengumpulkan dan membagikan zakat. 4. Muallaf: orang kafir yang ada harapan masuk Islam dan orang yang baru masuk Islam yang imannya masih lemah. 5. Memerdekakan budak: mencakup juga untuk melepaskan Muslim yang ditawan oleh orang-orang kafir. 6 . Orang berhutang: orang yang berhutang untuk kepentingan yang bukan maksiat dan tidak sanggup membayarnya. Adapun orang yang berhutang untuk memelihara persatuan umat Islam dibayar hutangnya itu dengan zakat, walaupun ia mampu membayarnya. 7. Pada jalan Allah (sabilillah): Yaitu untuk keperluan pertahanan Islam dan kaum muslimin. Diantara mufasirin ada yang berpendapat bahwa fi sabilillah itu mencakup juga kepentingan-kepentingan umum seperti mendirikan sekolah, rumah sakit dan lainlain. 8. orang yang sedang dalam perjalanan yang bukan maksiat mengalami kesengsaraan dalam perjalanannya.

Meskipun demikian kata miskin kadangkala ia disebutkan sendiri tanpa penyebutan kata faqir. Sebagaimana terdapat di dalam surat Al-Baqarah ayat177:

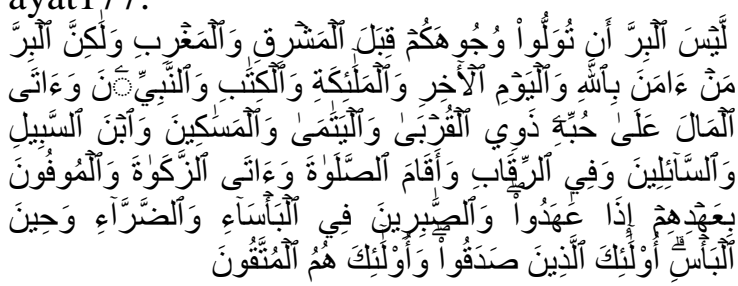

Bukanlah menghadapkan wajahmu ke arah timur dan barat itu suatu kebajikan, akan tetapi Sesungguhnya kebajikan itu ialah 
beriman kepada Allah, hari Kemudian, malaikat-malaikat, kitab-kitab, nabi-nabi dan memberikan harta yang dicintainya kepada kerabatnya, anak-anak yatim, orang-orang miskin, musafir (yang memerlukan pertolongan) dan orang-orang yang meminta-minta; dan (memerdekakan) hamba sahaya, mendirikan shalat, dan menunaikan zakat; dan orang-orang yang menepati janjinya apabila ia berjanji, dan orang-orang yang sabar dalam kesempitan, penderitaan dan dalam peperangan. Mereka Itulah orang-orang yang benar (imannya); dan mereka Itulah orang-orang yang bertakwa.

Menurut pemakalah, pembahasan tentang kata faqir dan miskin ini menjadi menarik dikarenakan dua hal. Pertama, penyebutan kata miskin di dalam AlQur'an lebih banyak daripada penyebutan kata faqir. Kata faqir disebutkan sebanyak 5 kali. Sedangkan al-fuqara disebutkan sebanyak 7 kali. $^{3}$ Kata Miskin disebutkan sebanyak 11 kali dan kata al-Masakin disebutkan sebanyak 12 kali. $^{4}$ Kedua, di dalam kasus-kasus fidyah dan kaffarat (baik sumpah, dzihar dan shaum) justru disebutkan untuk memberikan makanan (pakaian) kepada orang-orang miskin bukan kepada orang-orang faqir. Seperti yang disebutkan di dalam surat Al-Baqarah ayat 184.

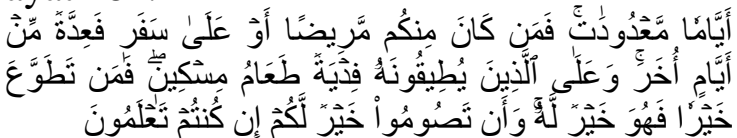
(yaitu) dalam beberapa hari yang tertentu. Maka Barangsiapa di antara kamu ada yang sakit atau dalam perjalanan (lalu ia berbuka), Maka (wajiblah baginya berpuasa) sebanyak hari yang ditinggalkan itu pada hari-hari yang lain. Dan wajib bagi orang-orang yang berat

\footnotetext{
${ }^{3}$ Muhammad Fuad Abdul Baqi, Al-Mu'jam al-Mufahras Li alfadz Al-Qur'an al-Karim, (Beirut, Dar al-Fikr: 1994), Cet.Ke-IV, h.666.

${ }^{4}$ Ibid., h. 449.
}

menjalankannya (jika mereka tidak berpuasa) membayar fidyah, (yaitu): memberi Makan seorang miskin. Barangsiapa yang dengan kerelaan hati mengerjakan kebajikan, Maka Itulah yang lebih baik baginya. Dan berpuasa lebih baik bagimu jika kamu mengetahui.

Maksudnya memberi Makan lebih dari seorang miskin untuk satu hari. Di samping itu ada ayat yang secara harfiah tidak menyebutkan faqir dan miskin akan tetapi memiliki makna faqir dan miskin sebagaimana firman Allah SWT di dalam surat al-Dzariyat ayat 19:

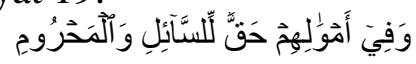

Dan pada harta-harta mereka ada hak untuk orang miskin yang meminta dan orang miskin yang tidak mendapat bagian dan Orang miskin yang tidak mendapat bagian Maksudnya ialah orang miskin yang tidak meminta-minta.

\section{B. Permasalahan}

Berdasarkan uraian singkat di atas, maka pemalakalah ingin mengajukan beberapa permasalahan yang berkaitan dengan kata faqir dan miskin yaitu:

1. Apa definisi faqir dan miskin menurut bahasa dan istilah?

2. Apa definisi faqir dan miskin menurut para mufassir?

3. Apa definisi faqir dan miskin menurut fiqh?

\section{Pembahasan}

1. Pengertian Faqir

a. Kata "faqir"terambil dari akar kata Faqira-Yafqaru-faqran, yang berarti mengeluhkan kemiskinanya disebabkan kebangkrutan atau karena sakit. Maka failnya adalah "Faqirun" dan"Faqiirun" Kata

\footnotetext{
${ }^{5}$ Ibrahim Anis, et.al.,Al-Mu'jam al-
}

Wasith, ( Mesir, Dar al-Ma'arif:1973), Cet Ke-8, Juz II, h,197. 
Faqir selanjutnya berarti: orang yang bangkrut dan miskin. ${ }^{6}$

b. Menurut kamus Al-ma'ani, kata faqir terambil dari akar kata faqirayafqaru-faqran, yang berarti mengeluhkan kebangkrutan dirinya disebabkan kemiskinan atau sakit. ${ }^{7}$ Sedangkan faqiir berarti orang yang membutuhkan yang tidak memiliki sumber-sumber penghasilan untuk mencukupi dirinya dan keluarganya. ${ }^{8}$ Juga kata faqiir adalah orang yang mengeluhkan rangkaian penderitaan dirinya disebabkan kebangrutan dan sakit. ${ }^{9}$

c. Ibnu Faris di dalam Mu'jam Li maqayis fii al-Lughah mengatakan bahwa kata "faqir" berasal dari kata faqara- yang berarti terbuka di dalam sesuatu. Baik dari anggota tubuh atau lainnya. Contohnya : kemiskinan. Al-faqir berarti orang yang bangkrut lagi miskin." 10

2. Pengertian Miskin

a. Selanjutnya kata Miskin berasal dari akar kata Sakana-yaskunusukuunan, yang berarti berhenti bergerak. ${ }^{11}$ Selanjutnya kata Miskin berarti orang yang tidak memiliki harta untuk mencukupi keluarganya, atau ia disebut Faqir. ${ }^{12}$ Di sini kata miskin disamakandengan faqir. Selanjutnya Miskin juga berarti

${ }^{6}$ Ibid.

${ }^{7}$ Al-Ma'any 'Araby-'Araby.

${ }^{8}$ Ibid.

${ }^{9}$ Ibid.

${ }^{10}$ Abu al-Husain Ahmad Ibn Farisi IbnZakariya, Mu'jam Al-Maqayis Fi Al-Lughah, (Beirut, Dar Al-Fikr, 1994), Cet. Ke-1, h. 792. Wasith, Juz I, h. 440.

${ }^{11}$ Ibrahim Anis, et. al., Al-Mu'jam al-

${ }^{12}$ Ibid. orang yang tunduk, patuh dan hina. ${ }^{13}$

b. Mu'jam al-Ma'any meyebutkan bahwa akar kata Miskin adalah Sakana-Yaskunu-Sukunan yang berarti berhenti bergerak. Sedangkan kata Miskin berarti "orang yang tidak memiliki harta untuk mencukupi keluarganya", atau ia disebut juga faqir. ${ }^{14}$ Di sini kata miskin juga memiliki kesamaan arti dengan kata faqir. Miskin dapat berarti juga "orang yang patuh, lemah dan hina. ${ }^{15}$

c. Pengertian Miskin di dalam Mu'jam al-Maqayis fi al-Lughah. Ibnu faris mengatakan bahwa kata miskin berasal dari kata sakanayaskunu-sukunan yang menunjukkan kepada lawan dari pergolakan dan pergerakan. ${ }^{16}$

3. Pengertian "Faqir" dan "Miskin" di dalam kitab-kitab tafsir.

a. Pengertian faqir di dalam tafsir Ibnu kathir. Ibnu Kathir ketika menafsirkan firman Allah surat alTaubah 60 mengatakan; Sesungguhnya Didahulukan penyebutan al-Fuqara dikarenakan mereka adalah orang yang paling membutuhkan dibandingkan dengan yang lain, menurut pendapat yang masyhur. Hal ini dikarenakan beratnya kemiskinan dan kebutuhan mereka. ${ }^{17}$ Abu Hanifah r.a. mengatakan bahwa kondisi alMasaakiin lebih buruk daripada al-

\footnotetext{
${ }^{13}$ Ibid.

${ }^{14} \mathrm{Al}-\mathrm{Ma}$ 'any 'Araby-'Araby. Online dictionary.

${ }^{15}$ Ibid.

${ }^{16}$ Abu al-Husain Ahmad Ibn Farisi
} IbnZakariya, Mu'jam Al-Maqayis Fi Al-Lughah, h. 486.

${ }^{17}$ Ibnu Kathir, Tafsir Al-Qur'an al- 'Adzim, (Riyadh, Dar Kunuz Eshbelia, 2009), Cet. ke-VIII, Jilid I, h.887. 
Fuqara. Hal ini sebagaimana disampaikan oleh Ibnu Jarir. Bahwasanya Ya'qub telah mengatakan kepada beliau, bahwasanya Ibnu 'Ulyah telah mengatakan kepada kami, Ibnu 'Aun telah menceritakan kepada kami dari Muhammad dia berkata, Umar r.a. telah berkata bahwasanya al-faqir bukanlah orang yang tidak memiliki harta, akan tetapi al-faqir adalah orang yang butuh pekerjaan. ${ }^{18}$ Ibnu 'Ulyah berkata, Al-Akhlaqu adalah Al-Muharaf yaitu orang yang tidak mendapatkan bagian yang meminta tetapi tidak diberi rizki. Ia merupakan lawan dari Mubarak. Yaitu yang mendapat berkah. ${ }^{19}$ Sedangkan jumhur ulama berpendapat berbeda. Sebagaimana diriwayatkan dari Ibnu 'Abbas, Mujahid dan Al-Hasan Al-Bashry, Ibnu Zaid, dan Ibnu Jarir serta yang lainnya memilih bahwasanya $A l$ Faqir adalah orang yang menjaga dirinya dari meminta-minta kepada manusia. Sedangkan al-Miskin adalah orang yang meminta dan berkeliling dan mengikuti manusia. ${ }^{20}$ Qatadah berkata, bahwa al-Faqir adalah orang yang memiliki sakit yang menahun. Sedangkan alMiskin adalah orang yang sehat jasmaninya. $^{21}$ Al-Thaury berkata, dari al-Manshur dari Ibrahim, bahwasanya mereka adalah orangorang faqir dari kaum al-Muhajirin. Sufyan al-Thaury berkata, mereka tidak diberikan apapun oleh orangorang Arab. Begitulah sebagaimana diriwayatkan dari Sa'id Ibn Jubair, Sa'id Ibn Abdu Al-Rahman Ibn
${ }^{18}$ Ibid.
${ }^{19}$ Ibid.
${ }^{20}$ Ibid.
${ }^{21}$ Ibid.
Abza. 'Ikrimah berkata, janganlah kalian mengatakan orang-orang faqir dari kaum muslimin itu adalah Masaakiin akan tetapi al-Masaakiin yang sesungguhnya adalah orangorang miskin Ahli Kitab. ${ }^{22}$ Terdapat beberapa hadith yang berkaitan dengan 8 golongan yang mendapatkan zakat. Adapun alFuqara, sebagaimana diriwayatkan dari Ibnu 'Amr ia berkata. Bahwasanya rasulullah SAW bersabda, " Tidak halal sedekah diberikan kepada orang yang kaya dan yang memiliki akal yang jelek." Diriwayatkan oleh Ahmad, Abu Dawud, al-Tirmidzi, Juga Ahmad dan al-Nasai juga Ibnu majah Memiliki riwayat yang serupa tetapi dari Abu Hurairah. ${ }^{23}$ Dari 'Ubaidillah ibn 'Adiy Ibn al-Khiyar, bahwasanya ada dua orang yang mengabarkan kepadanya bahwasanya keduanya telah mendatangi rasulullah SAW yang meminta sedekah. Maka rasulullah SAW membelalakkan matanya dan menyodorkan dua buah pecut. Jika kalian mau maka aku akan memberikan keduanya. Beliau bersabda, sesungguhnya sedekah itu tidak layak bagi orang kaya dan orang kuat yang memiliki pekerjaan. Diriwayatkan oleh Ahmad, Abu Dawud dan Al-Nasai dengan sanad yang baik. ${ }^{24}$ Ibnu Abu Hatim berkata di dalam kitab al-Jarh dan al-Ta'dil bahwa Abu Bakar al-'Abasy telah mengatakan bahwasanya Umar r.a. membaca "Innama al-shadaqat li alfuqara", mereka adalah Ahlu Kitab. Umar Ibn Nafi' meriwayatkan dari Umar. Aku telah mendengar
${ }^{22}$ Ibid.
${ }^{23}$ Ibid.
${ }^{24}$ Ibid., 888 
bapakku mengatakan hal itu. Aku berkata, ini adalah perkataan aneh sekali melihat sisi kekuatan isnadnya. Sesungguhnya Abu Bakr ini meskipun Abu Hatim tidak menghukumnya sebagai perawi yang asing, akan tetapi ia termasuk di dalam perawi yang majhul (yang tidak dikenal). ${ }^{25}$ Sedangkan alMasaakiin, Diriwayatkan dari Abu Hurairah r.a. bahwasanya rasulullah SAW bersabda, Orang miskin bukanlah orang yang berkeliling di antara manusa, kalian memberikannya satu dua suap, satu dua kurma. Para sahabat berkata, siapakah orang miskin itu ya rasulullah? Rasulullah menjawab, Orang miskin adalah orang yang tidak memiliki orang kaya yang mencukupinya, ia tidakdiperhatikan dan diberikan sedekah, tetapi ia tidak meminta-minta kepada manusia." (H.R. Al-Bukhari dan alMuslim). ${ }^{\text {‘26 }}$

b. Pengertian Faqir dan miskin menurut al-Zamashyari. Beliau menulis di dalam tafsirnya bahwasanya yang dimaksud dengan al-Fuqara di dalam surat al-taubah ayat $60 \mathrm{di}$ atas adalah orang-orang faqir di antara kaum muslimin dikarenakan mereka tidak memiliki pakaian. Sedangkan al-Masakiin adalah orang-orang yang selalu lembut kepada manusia dikarenakan ia tidak memiliki suatu apapun. Sebagaimana al-muskiir yaitu orang yang selalu mabuk. ${ }^{27}$

c. Pengertian "Faqir" dan "Miskin" menurut Al-Syarbainy. Ketika

\footnotetext{
${ }^{25}$ Ibid.

${ }^{26}$ Ibid.

${ }^{27}$ Al-Zamakhsyari, Al-Kasysyaf 'An
} Haqaiq al-Tanzil Wa 'Uyun al-Aqawil Fi Wujuh alTa'wil, (Kairo, Al-Quds: 2018), Cet.Ke I, Juz I, h. 194. menafsirkan ayat 60 dari surat altaubah, Al-Syarbainy mengatakan $l i$ al fuqara, al-faqir adalah seorang yang tidak mendapatkan sesuatu yang mencukupinya. Misalnya ia membutuhkan 10 dirham, akan tetapi ia tidak mendapatkannya kecuali dua atau tiga dirham,. Kata faqir terambil dari al-faqar seakanakan ia tertimpa kemiskinan. ${ }^{28}$ Sedangkan kata al-Masakin merupakan bentuk jamak dari miskin. Yaitu orang yang tidak mendapatkan sesuatu yang mencukupi kebutuhannya. Misalnya ia membutuhkan 10 dirham, akan tetapi ia hanya mendapatkan 7 atau 8 dirham. Kata miskin terambil dari kata al-sukun Seakan-akan kondisi lemahnya membuatnya diam. Orang miskin ini lebih tinggi posisinya daripada orang faqir. Hal ini ditunjukkan oleh firman Allah surat al-Kahfy ayat 79: "Adapun kapal itu milik otrang-orang miskin." Dan diriwayatkan dari rasulullah SAW bahwasanya Miskin ini lebih tinggi posisinya dari faqir. Dan dikatakan bahwasanya faqir itu lebih tinggi posisinya. Berdasarkan firman Allah: surat al-Balad ayat 16: "Atau orang miskin yang sangat faqir." "29

4. Pengertian Faqir dan miskin menurut al-Nasafy: Al-Nasafy menulis bahwa al-Faqir adalah orang yang tidak meminta-minta dikarenakan ia memiliki sesuatu yang mencukupi kebutuhannya. Sedangkan al-Miskin adalah orang yang meminta-minta dikarenakan ia tidak memiliki sesuatu yang menculupi kebutuhannya. Ia merupakan golongan yang lebih lemah

\footnotetext{
${ }^{28}$ Syamsuddin Muhammad Ibn

Muhammad Al-Syarbainy, Al-Siraj Al-Munir, (Cairo, Al-Quds, 2018), Cet.ke-I, h.316.. ${ }^{29}$ Ibid.
} 
dari semua golongan penerima zakat. Akan tertapi Al-Syafi'i berpendapat sebaliknya. Yaitu al-faqir lebih lemah kondisinya dari seluruh golongangolongan penerima zakat. ${ }^{30}$

B. Penafsiran Faqir dan Miskin menurut Al-Suyuthi di dalam tafsirnya al-Dur al-Manthur.

Ibnu al-Mundzir dan an-Nahhas meriwayatkan dari Ibnu 'Abbas ia berkata, Al-Fuqara adalah orang-orang faqir kaum muslimin dan al-masakiin adalah orangOrang yang berkeliling (untuk memintaminta). ${ }^{31}$ Abdu al-Razzaq, Ibnu alMundzir, Ibnu Abu Hatim , al-Nahhas dan Abu syaikh meriwayatkan dari Qatadah ia berkata, orang faqir adalah orang yang memiliki penyakit yang menahun, sedangkan orang miskin adalah orang yang membutuhkan yang tidak memiliki penyakit yang menahun. ${ }^{32}$ Ibnu $\mathrm{Abu}$ Hatim meriwayatkan dari Ibnu 'Umar, ia berkata, "Bukanlah dinamakan faqir seorang yang mengumpulkan dirham ke dirham lain, dan satu kurma ke kurma lain. Tetapi faqir itu adalah orang yang membersihkan pakaian dan dirinya dan ia tidak mampu untuk mencukupinya. Sebagaimana firman Allah SWT di dalam surat al-Baqarah ayat 273:

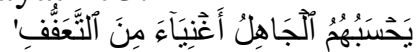

orang yang tidak tahu menyangka mereka orang kaya karena memelihara diri dari minta-minta...."

Ibnu Abu Syaibah meriwayatkan dari Jabir Ibn Zaid, ia berkata, al-fuqara adalah orang-orang yang menjaga diri mereka dari meminta-minta, sedangkan almasakin adalah orang-orang yang

\footnotetext{
${ }^{30}$ Abdullah Ibn Ahmad Ibn Mahmud al-
}

Nasafy, Tafsir al-Nasafy, (Beirut, Dar al-Kitab al'Araby, t.th), Juz II, h. 131-132.

${ }^{31}$ Al-Suyuthi, al-Dur al-manthur fi alTafsir al-Ma`thur, (Beirut, Dar al-Fikr:2011), Juz 4,h.221.

\footnotetext{
${ }^{32}$ Ibid.

${ }^{33}$ Ibid., h. 222 .
}

meminta-minta. Ibnu Abu Syaibah meriwayatkan dari al-Zuhri. Bahwasanya ia ditanya tentang ayat ini (al-taubah ayat 60). Ia menjawab, al-fuqara dalah orangorang yang berdiam di rumah dan tidak meminta-minta, sedangkan al-masakin adalah orang-orang yang keluar dari rumah-rumah mereka untuk memintaminta. ${ }^{34}$ Ibnu Abu Hatim meriwayatkan dari Mujahid. Ia berkata, al-faqir adalah orang yang menjadi faqir, ia berada di tengah-tengah kaumnya, keluarganya dan kerabatnya dan ia tidak memiliki harta. Sedangkan miskin adalah orang yang tidak memiliki keluarga juga kerabat tetapi ia memiliki harta. ${ }^{35}$

C. Penafsiran ulama terhadap ayat 19 surat al-Dzariyat:

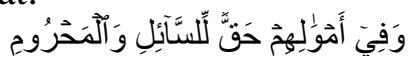

Dan pada harta-harta mereka ada hak untuk orang miskin yang meminta dan orang miskin yang tidak mendapat bagian.

Menurut Tafsir Quran Surat AzZariyat Ayat 19. Dan di dalam harta mereka terdapat hak (jatah) -mereka berderma dengannya- bagi orang yang meminta dan bagi orang yang tidak meminta dari siapa saja yang terhalang rezekinya karena sebab apa pun. ${ }^{36}$ Menurut Tafsir Al-Mukhtashar / Markaz Tafsir Riyadh, di bawah pengawasan Syaikh Shalih bin Abdullah bin Humaid (Imam Masjidil Haram). Pada harta mereka terdapat hak wajib dan sunnah untuk orang-orang yang membutuhkan yang meminta kepada orang-orang dan orangorang yang membutuhkan tetapi tidak meminta-minta karena malu. ${ }^{37}$

Menurut Tafsir Al-Muyassar / Kوَفِنَ . Kementerian Agama Saudi Arabia (Dan pada harta-

\footnotetext{
${ }^{34}$ Ibid.

${ }^{35}$ Ibid.

${ }^{36} \mathrm{https}$ ://tafsirweb.com/9915-quran-surataz-zariyat-ayat-19.html

${ }^{37}$ Ibid.
} 
harta mereka ada hak untuk orang miskin yang meminta dan orang miskin yang tidak mendapat bagian) Makna (السائل) yakni orang faqir yang tidak memiliki apapun, kemudian meminta bantuan dari orang lain. Sedangkan (المحروم) yakni orang yang tidak mampu bekerja, namun dia menolak untuk meminta-minta, sehingga dianggap orang lain sebagai orang yang tidak butuh bantuan, sehingga tidak ada orang yang bersedekah kepadanya. Pendapat lain mengatakan ia adalah orang yang tertimpa musibah. ${ }^{38}$ Menurut Zubdatut Tafsir Min Fathil Qadir / Syaikh Muhammad Sulaiman Al Asyqar, mudarris tafsir Universitas Islam Madinah. Di dalam harta mereka ada bagian untuk orang faqir yang tidak memiliki apapun dan orang lemah yang tidak mampu melakukan usaha apapun atau orang faqir yang lemah. ${ }^{39}$ Menurut Tafsir Al-Wajiz / Syaikh Wahbah al-Zuhaili, pakar fiqih dan tafsir negeri Suriah. Mereka juga mewajibkan atas diridiri mereka untuk bersedekah kepada orang-orang yang membutuhkan, yang meminta-minta kepada manusia, dan bagi mereka yang malu untuk meminta. Mereka melakukan ini semua karena ingin mendekatkan diri kepada Allah. ${ }^{40}$

D. Pengertian "Faqir" dan "Miskin"
menurut fiqh

Dalam hal ini penulis hanya mengutip sekilas apa yang terdapat di dalam kitab fiqh al-Sunnah karangan alsayyid Sabiq. Al-Fuqara dan al-Masakin mereka adalah orang-orang yang membutuhkan yang tidak dapat memenuhi apa yang mereka butuhkan. Golongan ini merupakan lawan dari orang-orang kaya yang dapat memenuhi kebutuhan mereka. Kadar yang mennetukan bahwasanya seseorang itu kaya adalah kadar nishab yang lebih dari kebutuhan dasar bagi

\footnotetext{
${ }^{38}$ Ibid.

39 Ibid.

${ }^{40}$ Ibid.
}

dirinya dan anak-anaknya. Baik berupa sandang, pangan, papan, alat transportasi, alat-alat untuk bekerja dan lain sebagainya. Maka bagi siapa yang tidak memenuhi kadar atau kriteria di atas tersebut, maka ia adalah faqir yang berhak untuk mendapatkan zakat. Sebagaimana disebutkan di dalam hadith Muadz, "Zakat itu diambil dari harta-harta orang kaya untuk dikembalikan kepada orang-orang faqir mereka." Maka harta zakat itu diambil dari harta orang kaya yang telah mencap[ai nishab. ${ }^{41}$

Zakat itu diberikan kepada orang faqir yang tidak memiliki kadar seperti yang dimiliki oleh orang kaya. Tidak ada perbedaan antara orang-orang faqir dan miskin dilihat dari sisi kebutuhan dan kemiskinan. Dan mengumpulkan penyebutan kata faqir dan miskin di dalam ayat di atas menuntut adanya pembedaan. Sesungguhnya orang-orang miskin adalah suatu kelompok dari orang-orang faqir. Hal ini dikarenakan terdapat keterangan khusus yang menjelasan perbedaan mereka dengan faqir. Sebagaimana hadith dari Abu Hurairah, bahwasanya rasulullah SAW bersabda, "Orang miskin bukanlah orang yang berkeliling di antara manusa, kalian memberikannya satu dua suap, satu dua kurma. Para sahabat berkata, siapakah orang miskin itu ya rasulullah? Rasulullah menjawab, Orang miskin adalah orang yang tidak memiliki orang kaya yang mencukupinya, ia tidak diperhatikan dan diberikan sedekah, tetapi ia tidak memintaminta kepada manusia." (H.R. Al-Bukhari dan al-Muslim). ${ }^{42}$

\section{Kesimpulan}

Dapat disimpulkan di sini bahwa Pengertian faqir menurut bahasa adalah

\footnotetext{
${ }^{41}$ Al-Sayyid Sabiq, Fiqh al-Sunnah, (Beirut, Dar al-Kitab al-'Araby, T.th), Juz I, h.383.

${ }^{42}$ Ibid., h.383-384.
} 
orang yang bangkrut yang membutuhkan sesuatu yang mencukupi kebutuhannya. Sedangkan karta miskin adalah orang yang diam tidak mampu bergerak atau berusaha dikarenakan kondisi kemiskinan yang menimpanya. Para mufassir berbeda-beda di dalam menafsirkan kata faqir dan miskin. Ada yang mengatakan bahwa orang faqir lebih lemah kondisinya daripada orang miskin. Sebaliknya ada yang berpendapat bahwa orang miskin lebih lemah kedudukannya daripada orang faqir. Masing-masing memberikan argumentasi yang berbeda dengan menggunakan dzahir ayat al-Qur'an dan keterangan hadith nabi SAW.

Dalam term fiqih, orang faqir adalah orang yang membutuhkan berbagai hal yang ia tidak sanggup untuk memenuhinya. Istilah faqir ini merupakan lawan dari Ghany (orang kaya), di mana yang terakhir ini adalah orang-orang yang mampu untuk memenuhi kebutuhan mereka. Ada yang menyamakan istilah faqir dan miskin. Di samping itu ada pula yang membedakannya dengan menggunakan keterangan dari hadith nabi SAW dari Abu Hurairah R.A. Menurut penulis, faqir dapat disamakan dengan term Al-Sail (orang miskin yang meminta) dan term miskin dapat disamakan dengan "Al-mahrum (orang miskin yang tidak mendapatkan bagian) dikarenakan mereka menjaga kehormatan diri mereka. Kesimpulan ini diambil setelah memperhatikan berbagai uraian di atas dan hadith shahih yang diriwayatkan oleh Abu Hurairah di atas. Penyebutan kata miskin yang lebih banyak daripada faqir di dalam Al-Qur'an mengindikasikan bahwa kata miskin lebih rendah kedudukannya daripada faqir. Juga dimungkinkan bahwa kondisi faqir merupakan kondisi yang dibenci di dalam Islam dengan hadith yang mengatakan "bahwa hampir saja kefakiran itu membawa kepada kekufuran", maka sebelum orang itu menjadi faqir maka ia harus ditolong terlebih dahulu.

\section{DAFTAR PUSTAKA}

Al-Qur'an dan Terjemahnya, Kementrian Agama Republik Indonesaia.

Al-Ma'any 'Araby-'Araby. Online dictionary.

Anis, Ibrahim, et.al.,Al-Mu'jam al-Wasith, ( Mesir, Dar al-Ma'arif:1973), Cet Ke-8, Juz II, h,197.

Baqi, al, Muhammad Fuad Abdu, AlMu'jam al-Mufahras Li alfadz Al-

Qur'an al-Karim, (Beirut, Dar al-

Fikr: 1994), Cet.Ke-IV.

Ibn Zakariya, Abu al-Husain Ahmad Ibn Farisi, Mu'jam Al-Maqayis Fi Al-

Lughah, (Beirut, Dar Al-Fikr, 1994), Cet. Ke-1.

Kathir, Ibnu, Tafsir Al-Qur'an al-'Adzim, (Riyadh, Dar Kunuz Eshbelia, 2009), Cet. ke-VIII, Jilid I.

Nasafy, al, Abdullah Ibn Ahmad Ibn Mahmud, Tafsir al-Nasafy, al (Beirut, Dar al-Kitab al-'Araby, t.th), Juz II.

Sabiq, al-Sayyid, Fiqh al-Sunnah, (Beirut, Dar al-Kitab al-'Araby, T.th), Juz I.

Suyuthi, al, al-Dur al-Manthur fi al-Tafsir al-Ma'thur, (Beirut, Dar alFikr:2011), Juz 4.

Syarbainy, al, Syamsuddin Muhammad Ibn Muhammad, Al-Siraj AlMunir, (Cairo, Al-Quds,2018), Cet.ke-I.

Referensi: https://tafsirweb.com/9915quran-surat-az-zariyat-ayat-19.html

Zamakhsyari, al, Al-Kasysyaf 'An Haqaiq al-Tanzil Wa 'Uyun al-Aqawil FiWujuh al-Ta'wil,(Kairo, AlQuds: 2018), Cet.Ke I, Juz I.

https://www.kbbi.web.id/faqir https://www.kbbi.web.id/miskin 
Perbandingan Tafsir Kata Faqir Dan Miskin Dalam Al-Qur'an 